\title{
Nephrotoxicity of iodinated contrast media: from pathophysiology to prevention strategies
}

\section{Anne-Laure Faucon ${ }^{1,2}$, Guillaume Bobrie ${ }^{1}$, Olivier Clément ${ }^{2,3,4}$}

${ }^{1}$ AP-HP, Hôpital Européen Georges Pompidou, Department of Nephrology and Hypertension, F-75015 Paris, France

2Université Paris-Descartes, Faculty of Medicine, F-75006 Paris, France

${ }^{3}$ AP-HP, Hôpital Européen Georges Pompidou, Department of Diagnostic Radiology, F75015 Paris, France

${ }^{4}$ Laboratory for Imaging Research, PARCC, INSERM UMR 970, Paris, France

Corresponding author: Anne-Laure Faucon, AP-HP, Hôpital Européen Georges Pompidou, Department of Nephrology and Hypertension, 20 rue Leblanc, 75015 Paris, France; email: anne-laure.faucon@aphp.fr

Disclosure: The authors have no conflict of interest to declare. 


\section{Nephrotoxicity of iodinated contrast media: from pathophysiology to prevention strategies}

\section{Abbreviations}

ACR: American College of Radiology

AKI: acute kidney injury

CKD: chronic kidney disease

ERBP: European Renal Best Practice

ESUR: European Society of Urogenital Radiology

GFR: glomerular filtration rate

ICM: iodinated contrast media

KDIGO: Kidney Disease: Improving Global Outcomes

KIM-1: kidney injury molecule-1

NGAL: neutrophil gelatinase-associated lipocalin

NO: nitric oxide

ROS: reactive oxygen species

TAL: thick ascending limb of the loop of Henle

Word count: Abstract: 203 words; Article: 4631 words; References: 122; Tables: 5; Figures: 


\begin{abstract}
Iodinated contrast media (ICM) induced acute kidney injury (AKI) accounts for $11 \%$ of cases of AKI and is its third most common cause in hospitalized patients. However, the pathophysiological mechanisms are not yet completely understood. The nephrotoxicity of ICM is partly the consequence of a direct cytotoxic effect on renal tubular epithelial and endothelial cells. It is also the consequence of impaired intrarenal hemodynamics, these two mechanisms being closely linked. The rheological properties of ICM, the volume infused, and the route of administration increase the intrinsic toxicity generated by the contrast media used. Furthermore, various clinical situations increase the risk of developing AKI. There is no specific treatment. Hydration is the cornerstone of prevention. Preventive measures have reduced the incidence of AKI over the last ten years. After an overview of the pathophysiology of the renal toxicity of ICM, we review risk factors and scores, diagnosis, and means of prevention in the light of the 2018 European Society of Urogenital Radiology and the 2018 American College of Radiology guidelines and recent studies on the subject. In addition, a side-by-side comparison of the updated and less conservative guidelines from the Radiology community and the more cautionary attitude from the Nephrology community are also presented.
\end{abstract}

Keywords: acute kidney injury, contrast-induced nephropathy, iodinated contrast media. 


\section{Introduction}

Iodinated contrast media (ICM) are nephrotoxic and can cause acute kidney injury (AKI) or be responsible for the worsening of chronic kidney disease (CKD). There is no consensus on the definition of iodinated contrast media-induced AKI. In accordance with the European Society of Urogenital Radiology (ESUR), the definition widely used in both interventional and observational studies is an increase in serum creatinine by $44 \mu \mathrm{mol} / \mathrm{L}$ or by a more than $25 \%$ increase from baseline, occurring in the 72 hours following the injection of ICM, in the absence of another cause for renal failure [1].

ICM-induced AKI is the third most common cause of acute renal failure in hospitalized patients, after renal hypoperfusion and medications [2]. It accounts for $11 \%$ of the causes of AKI. The introduction of preventive measures has reduced its incidence over the last 10 years, from 15 to $7 \%$ [3]. Its incidence is currently estimated at between 3.3 and 10.5\% [4-6], and up to $10-20 \%$ or even $50 \%$ in high risk patients [7], depending on the definition used. Even if the outcome of AKI is often favorable, it is well known that AKI per se is an independent risk factor for CKD [3,8,9], cardiovascular events and mortality [9-11]. Resorting to dialysis remains rare in the general population $(<1 \%)[3,12]$, but can reach $7 \%$ in case of pre-existing CKD [13]. The increased risk of mortality persists over one to five years, especially in patients on hemodialysis therapy [14].

After an initial section on the pathophysiology of renal ICM toxicity, this review will successively discuss risk factors and scores, diagnosis, and means of prevention in the light of recent guideline updates and recent studies in this field. 


\section{Pathophysiology}

ICM-induced AKI occurs rapidly after the administration of radiopaque media, with an increase in serum creatinine concentration detectable after 48 hours; it reaches a maximum after three to five days, and usually returns to its baseline value around the tenth day (range, one to three weeks) $[15,16]$.

Renal involvement related to ICM consists of tubular injury (Figure 1). Renal toxicity of ICM is partly the consequence of a direct, intrinsic cytotoxic effect on renal tubular epithelial and endothelial cells. It is also the consequence of an impairment of intrarenal hemodynamics, these two mechanisms being closely linked. High ICM osmolality, viscosity, and volume as well as route of administration (intra-arterial versus intravenous) increase the intrinsic toxicity generated by the contrast agent used $[16,17]$.

\section{Tubular epithelial and endothelial cytotoxicity of ICM}

ICM are tri-iodinated benzene derivatives. "Iodine", in its ionic $\left(\mathrm{I}^{-}\right)$, molecular $\left(\mathrm{I}_{2}\right)$, or hydrated $\mathrm{H}_{2} \mathrm{OI}^{+}$form is an antiseptic agent capable of lysing bacterial walls due to its oxidizing power.

The iodine contained in ICM has a direct toxic effect on human cells, and in particular on renal tubular epithelial cells (vacuolization of tubular cells and osmotic nephrosis) and on endothelial cells. The exact pathophysiological mechanism of this cytotoxicity remains unknown. Several mechanisms may be involved (Figure 1). ICM could act by directly stimulating the signaling pathways involved in apoptosis via an activation of caspases-3 and -9 and the bcl2 pathway [18], and by disrupting mitochondrial activity [19], independently of oxidative and hypoxic stress and of physicochemical properties of ICM [20].

Furthermore, by their strong oxidizing power, ICM stimulate the synthesis of reactive oxygen species (ROS) that are toxic to endothelial and tubular epithelial cells, among others. ROS stimulate the $\mathrm{JNK} / \mathrm{p} 38$ signaling pathway involved in the activation of apoptosis intrinsic pathway [21]. However, according to Liu et al, the increase in ROS synthesis appears to be 
more a consequence of direct ICM toxicity on tubular cells than the cause of cellular damage [22]. Thus, ROS would only accentuate the cell damage caused by the administration of ICM.

Finally, hyperosmolality increases the intrinsic toxicity of ICM. In vitro, the osmolar power of ICM has been shown to exert a toxic effect on tight junction proteins [23,24], and ICM hypertonicity also induces DNA fragmentation and tubular cell apoptosis [25].

\section{Impairment of intra-renal hemodynamics}

ROS induce an increase in the synthesis of endothelin, angiotensin II, adenosine and thromboxane $\mathrm{A} 2$, and a reduction in the synthesis of nitric oxide (NO). The vasa recta, peritubular capillaries and glomerular capillaries acquire a "vasoconstriction" phenotype [26], causing endothelial cell dysfunction, which can be accentuated in case of pre-existing endothelial dysfunction (CKD, diabetes). Endothelial cells then become very sensitive to angiotensin II. Furthermore, after ICM injection the increase in ROS synthesis (in particular $\mathrm{O}_{2}^{-}$), induces an increase in tubuloglomerular feedback in the distal convoluted tubule, increasing renal hypoperfusion [22]. Superoxide anion $\left(\mathrm{O}_{2}^{-}\right)$also reduces the bioavailability of NO in the thick ascending limb of the loop of Henle (TAL) [27] and stimulates the reabsorption of $\mathrm{NaCl}$ in this tubular segment [28-30]. TALs located in the outer medulla are sensitive to hypoxia, as in the basal state tubular reabsorption of sodium, the initial passage of blood into the cortex, and the vasa recta-TAL distance ("physiological" shunt effect) create a situation of relative renal parenchymal hypoxia [31,32]. Consequently, owing to the ICMinduced increase in tubular sodium reabsorption the kidney's oxygen requirement rapidly becomes much higher than oxygen supply, thus worsening the pre-existing state of renal tubular hypoxia.

In addition, ICM hyperviscosity further impairs glomerular hemodynamics by inducing a reduction of blood flow in both glomerular and tubular capillaries, and by slowing the flow of tubular fluid, thereby increasing contact time with ICM and their cytotoxicity. In addition, owing to negligible or no tubular reabsorption, ICM concentration rises progressively on its way through the tubular segments, to become highly concentrated in the medullary part of the distal nephron. The tubular concentration process enhances fluid viscosity in an exponential manner [33]. 
Finally, hypoperfusion of the medulla is further enhanced by changes in red blood cell structure and function including dessicocyte and echinocyte formation, enhanced rigidity, and diminished $\mathrm{O}_{2}$ transport capacity induced by the ICM itself [34].

The result is an impairment of intra-renal hemodynamics, hypoxia, ischemia, and eventually tubular cell necrosis, leading to an increased synthesis of pro-inflammatory cytokines and ROS and thus creating a vicious circle. Being very sensitive to hypoxia, the renal medulla with its physiological partial pressure of $\mathrm{O}_{2}$ of only $10-30 \mathrm{mmHg}$ [35], is the region of the kidney which is most severely affected by the oxidative and ischemic changes induced by ICM.

\section{Towards a reduction in the nephrotoxicity of iodinated contrast media}

ICM are tri-iodinated benzene derivatives (Figure 2). Their synthesis consists of the fixation of 3 radiopaque iodine atoms onto hydrosoluble carbon atoms (benzene ring) [24]. As mentioned above, the physical and rheological properties of ICM (osmolality and viscosity) increase their intrinsic cytotoxicity. In the 1950s, the first ICM used were ionic tri-iodinated monomers, that is, combined with a cation (sodium and/or meglumine). In solution, the ICM separates into two particles: the benzene ring and the cation, which doubles their osmolality. To reach a sufficient quantity of iodine for radiological opacification (around $300 \mathrm{mg}$ of iodine $/ \mathrm{mL})$, the osmolality of the ICM has to be 5 to 6 times higher than that of plasma $(1,530$ to $1,860 \mathrm{mOsmol} / \mathrm{kg} \mathrm{H}_{2} \mathrm{O}$ ), thus considerably increasing their toxicity. From the $1970 \mathrm{~s}$, the osmolality of ICM has been reduced either by duplicating the ionic monomer (dimerization), or by substituting the acid function of the benzene ring for an amide function (Figure 2). In the first case, obtaining a hexa-iodinated ionic dimer enables an increase in the iodine concentration while reducing the osmolality of the ICM. In the second case, as the substitution of the acid function for an amide function (tri-iodinated nonionic monomers) does not require the addition of a cation, the osmolality of the solution is reduced. Modification of the chemical structure of ICM made it possible to reduce their osmolality to $600 \mathrm{mOsmol} / \mathrm{kg}$ $\mathrm{H}_{2} \mathrm{O}$. Since 1980, another approach has been developed for obtaining osmolality close to that of plasma (290 mOsmol/kg $\mathrm{H}_{2} \mathrm{O}$ ), by creating hexa-iodinated nonionic dimers. Four families of ICM are currently marketed: ionic monomers and dimers, and nonionic monomers and dimers (Table 1, Figure 2) [36]. While low osmolality ICM are associated with a lower risk of 
AKI than ICM with a higher osmolality [37], the results of studies comparing low osmolality ICM and iso-osmolar ICM remain controversial [38-41].

\section{Risk factors for acute kidney injury}

The most significant risk factor is pre-existing CKD [42]. There is a strong correlation between the risk of ICM-induced AKI and the degree of kidney disease. Other factors such as diabetes, age, dehydration, proteinuria, or nephrotoxic medication also increase the risk of AKI $[42,43]$ (Table 2). ICM with high osmolality, high viscosity, repeated ICM injection within a short interval (48-72h) [44], and intra-arterial administration represent further risk factors for AKI. In the case of intra-arterial injection, the ICM dose used is often higher, and its renal intravascular concentration is higher, increasing the risk of AKI $[1,42,45]$. However, retrospective studies reported a similar risk of AKI in patients who underwent either route of administration $[46,47]$. The injected volume of ICM is another risk factor that must be taken into account. Although there is no threshold dose, the risk of kidney failure has been shown to double with every $20 \mathrm{~mL}$ increase of ICM [17]. According to Laskey et al., an ICM volume to creatinine clearance ratio greater than 3.7 is an independent predictive factor for an increase in serum creatinine following ICM injection, in any population [48]. Furthermore, Nyman et al. showed that a ratio $<1$ of iodine quantity $(\mathrm{g})$ / estimated glomerular filtration rate (eGFR, $\mathrm{mL} / \mathrm{min} / 1.73 \mathrm{~m}^{2}$ using MDRD equation) was associated with a $3 \%$ risk of AKI, as compared to a $25 \%$ risk with an iodine quantity / eGFR MDRD ratio $\geq 1$ [49]. All these factors potentially combine to increase the risk of AKI.

In the 2018-ESUR guidelines, the traditional non-renal risk factors are now considered as non-specific for post-contrast AKI. In addition, compared to the previous guidelines, intraarterial route was split in first and second pass renal exposure, i.e. when ICM reaches the renal arteries in either undiluted or diluted form. This distinction led to a decrease in GFR threshold as a risk factor for AKI to $<45 \mathrm{~mL} / \mathrm{min} / 1.73 \mathrm{~m}^{2}$ before intra-arterial ICM administration with first pass renal exposure, and to $<30 \mathrm{~mL} / \mathrm{min} / 1.73 \mathrm{~m}^{2}$ before intravenous injection or intra-arterial injection with second pass renal exposure [42]. However, these new, less conservative recommendations need to be debated and validated (or not) by the Nephrology community. 
Can the risk of ICM-induced nephropathy be precisely predicted? In 2004, Merhan et al. developed a risk stratification scoring system for intra-arterial injections of ICM, based on 8 variables (Table 3) [50]. According to this study, if the score is $\leq 5$, the incidence of nephropathy is $7.5 \%$, that of dialysis $0.04 \%$, and that of and mortality at one year $1.9 \%$ after intra-arterial injection of ICM. On the other hand, for a score greater than 16, estimated risks are $57.3 \%, 12.6 \%$ and $31.2 \%$ respectively. However, the score does not take into account the existence of proteinuria, use of nephrotoxic medications, presence or absence of prior hydration, or serum creatinine 48 hours later. Prediction models using statistical tools such as a propensity score, also appear to be unable to predict the risk of ICM-induced nephropathy, and sometimes lead to unexpected findings [51,52]. Out of the 12 scores and prediction models studied by Silver et al., none appeared to be able to precisely evaluate or predict the risk of ICM-induced nephropathy in the context of coronary angiography [53]. In addition, no risk prediction scores are available for CT-scan. Nevertheless, all patients receiving ICM should be evaluated for the risk of AKI. According to the 2018-American College of Radiology (ACR) guidelines, patients with one of the following risk factors, age $>60$ years, history of renal disease (dialysis, kidney transplant, single kidney, renal cancer, renal surgery), history of hypertension requiring medical therapy, history of diabetes mellitus, and metformin treatment, do require a baseline serum creatinine determination before ICM injection [36].

\section{Diagnosis}

"ICM-induced AKI" should be distinguished from "post contrast-induced AKI" [36,42]. The term "ICM-induced" should be used to describe only AKI caused by the ICM per se, thus being a causal diagnosis. Conversely, the term "post contrast-induced" should be used for deteriorations of kidney function following ICM injection, without evidence of direct renal toxicity. It can be induced by many other causes, for instance hemodynamic instability or cholesterol embolism. However, causal diagnosis of AKI is sometimes misinterpreted and wrongly attributed to the ICM. ICM-induced AKI occurs rapidly after administration of the radiopaque media, resulting in acute tubular necrosis. Currently, there is no consensus on the definition of ICM-induced AKI. The definition generally used is an increase in serum creatinine concentration by $44 \mu \mathrm{mol} / \mathrm{L}(0.5 \mathrm{mg} / \mathrm{dL})$ or by more than $25 \%$ compared to baseline, within 72 hours following the ICM injection, in the absence of other identified AKI causes [1]. The recently updated ESUR guidelines recommend using the Kidney Disease Improving 
Global Outcomes (KDIGO) defined stage 1 classification of AKI: an increase in serum creatinine $\geq 26.5 \mu \mathrm{mol} / \mathrm{L}(0.3 \mathrm{mg} / \mathrm{dL})$, or $\geq 1.5-1.9$ times baseline [54], within $48-72 \mathrm{~h}$ following ICM administration [42]. Use of serum creatinine as a diagnostic marker has certain limitations [55]. Serum creatinine reflects GFR impairment but is not a marker for renal "injury" (in the way that troponin is a marker for cardiomyocytes injury). Furthermore, serum creatinine concentration increases late and remains insensitive, especially when renal function is normal at baseline (the creatinine/GFR relationship is an inverse hyperbolic curve). Other biomarkers such as cystatin-C, neutrophil gelatinase-associated lipocalin (NGAL) or kidney injury molecule-1 (KIM-1), which are early markers for renal tubular dysfunction, appear to be more sensitive and specific in establishing the diagnosis of AKI [56,57]. Cystatin-C would be a more sensitive biomarker than creatinine for detecting rapid variations in GFR [58,59], enabling an earlier diagnosis of AKI $[56,60]$. It would also be a predictive marker for the occurrence of serious adverse events in patients with CKD after ICM injection [56,61]. In addition, an increase in KIM-1 and NGAL levels are respectively associated with proximal [56,62], and distal tubular damage [63]. Finally, as impairment of intra-renal hemodynamics and hypoxia are pivotal element in pathophysiology, functional imaging techniques (such as blood oxygen level-dependent magnetic resonance imaging, BOLD-MRI) develop as diagnostic tools to assess renal hemodynamics and oxygenation [64]. These different approaches are not yet routinely used.

\section{Treatment and prevention}

There is no specific treatment for ICM-induced acute tubular necrosis. Symptomatic treatment is based on the maintenance or restoration of a correct state of hydration and discontinuation of nephrotoxic drugs. Even if hemodialysis and hemofiltration can remove ICM [65], prophylactic hemodialysis has not been shown to be beneficial either on the incidence of AKI, on renal outcome, or on morbidity and mortality $[66,67]$, and is not recommended by KDIGO [54], European Renal Best Practice (ERBP) [68], or ESUR guidelines [69,70]. However, it could have a place in case of volume overload or hyperkalemia, that are refractory to medical treatment.

The best approach to limit ICM-induced renal toxicity is still prevention. It is based on discontinuing nephrotoxic drugs (NSAIDs...) 48 hours before the examination, maintaining 
sufficient hydration (stopping diuretics 48 hours before), removal of conditions causing an increase in plasma osmolality (hyperglycemia, intravenous immunoglobulin) and screening for at-risk patients, and finally, avoiding ICM injection if possible, or considering an alternative imaging method such as MRI or ultrasound, especially when renal function is impaired (Table 4). If ICM injection cannot be avoided, ICM with low osmolality and low viscosity should be preferentially used (Table 1). However, the "ideal" ICM remains to be determined, as the lower the osmolality of ICM, the higher is its viscosity [17]. Finally, the volume of ICM administered should be as low as possible. It should not exceed three times the value of GFR, in milliliters (using ICM 350mg iodine/ml) [42].

\section{Hydration}

Hydration is the cornerstone of preventive treatment [71]. Hydration enables a reduction in the tubular concentration of ICM and its viscosity, a less marked stimulation of the reninangiotensin-aldosterone system, inhibition of antidiuretic hormone synthesis, and minimization of the reduction of NO and prostacyclin synthesis [72], thus reducing kidney hypoperfusion and medullary hypoxia. Diuretics should be stopped 48 hours before the examination. Recommended methods of hydration vary. In the majority of cases, oral intake of water and $\mathrm{NaCl}$ for 48 hours is sufficient. However, in at-risk patients, oral hydration should be reinforced and supplemented with intravenous administration of $\mathrm{NaCl}$ (Table 4). Oral water intake, by suppressing vasopressin release, leads to a rapid increase in diuresis and provides rapid short-term renal protection. Conversely, the renal response to intravenous administration of isotonic saline is delayed - as saline loading suppresses the renin-angiotensin-aldosterone system - but offers long-lasting renal protection. Intravenous $\mathrm{NaCl} 0.9 \%$ or sodium bicarbonate $1.4 \%$ can be used and must be started hours before exposure to ICM. In addition to its effect on volemia, sodium bicarbonate reduces ROS synthesis [73]. However, the results of studies comparing sodium bicarbonate with $\mathrm{NaCl}$ remain controversial [74]. In 2013, Weisbord et al. examined the 17 clinical trials and 12 meta-analyses on the subject. The small number of people included, the heterogeneity of inclusion criteria and hydration protocols, the use of surrogate primary endpoints, the absence of long-term follow-up, as well as study heterogeneity and publication bias did not enable a firm conclusion to be drawn regarding a potential superiority of bicarbonate versus $\mathrm{NaCl}$ [74]. 
In 2017, the Dutch monocentric open-label randomized trial AMACING, conducted between 2014 and 2016, showed that the absence of prophylaxis was non-inferior to intravenous hydration with $\mathrm{NaCl}$ (the absolute difference in incidence was $-0.1 \%$ (one-sided $95 \%$ confidence interval: $[-2.25 ; 2.06]$; one-tailed $\mathrm{p}=0.471)$, in preventing the risk of occurrence of contrast-induced nephropathy, among 660 ambulatory patients with CKD stage 3 [75]. However, these results should be interpreted with caution. First, they may not apply to hospitalized patients or patients referred for an emergent procedure. Second, it is well known that the current definition of CKD is very sensitive, but poorly specific, resulting in inclusion of a broad range of CKD severity (from renal senescence to "true" renal disease, i.e. from a relative low-risk to a very high-risk profile). In this study patients' mean age was 72 years and mean baseline serum creatinine $118 \mu \mathrm{mol} / \mathrm{L}$, suggesting that renal "senescence" was the primary driver of CKD diagnosis and may not reflect "true" intrinsic renal disease. Third, the mean administered volume of ICM was lower $(90.5 \mathrm{~mL})$ than three times the mean baseline GFR of $47 \mathrm{~mL} / \mathrm{min} / 1.73 \mathrm{~m}^{2}$, and only $<16 \%$ of patients were referred for an interventional procedure. Finally, the observed event rate in these intermediate-risk patients was lower (2.6$2.7 \%$ ) than that previously reported in the literature.

Very recently, the large prospective PRESERVE trial randomly assigned 5,177 patients at risk for renal complications (median eGFR, $50 \mathrm{ml} / \mathrm{min} / 1.73 \mathrm{~m}^{2}$ ) to receive intravenous $\mathrm{NaCl}$ or sodium bicarbonate solution, and oral $\mathrm{N}$-acetylcysteine or placebo, in a $2 \times 2$ factorial design [76]. In this well conducted and sufficiently powered clinical trial using a relevant primary outcome of major adverse kidney events (MAKE), i.e. a composite end-point including death, dialysis or a persistent decline in GFR at 90 days, there was no benefit of sodium bicarbonate over $\mathrm{NaCl}$ or of $\mathrm{N}$-acetylcysteine over placebo. However, this study included low to moderate-risk patients (according to Mehran score), and whether this result would extend to high-risk patients, the use of higher doses of ICM (i.e. complex intervention procedures), or intravenous ICM administration remains unclear.

The ESUR guidelines recommend for both intravenous and intra-arterial ICM administration with second pass renal exposure, an intravenous hydration with $\mathrm{NaCl} 0.9 \%$ at $1.0 \mathrm{~mL} / \mathrm{kg} / \mathrm{h}$ for 3-4 hours before the injection and continuing for 4-6 hours after the procedure, or the intravenous administration of sodium bicarbonate $1.4 \%(154 \mathrm{mEq} / \mathrm{L}), 3 \mathrm{mg} / \mathrm{kg} / \mathrm{h}$ starting 1 hour before the injection of ICM (followed by $1 \mathrm{mg} / \mathrm{kg} / \mathrm{h}$ for $4-6$ hours after intra-arterial ICM administration with first pass renal exposure) $[69,70]$. The KDIGO guidelines suggest $\geq 1-1.5$ 
$\mathrm{mL} / \mathrm{kg} / \mathrm{h}$ infusion of crystalloid 3-12 hours before and 6-12 hours after ICM exposure, in order to achieve a urine ouput $>150 \mathrm{~mL} / \mathrm{h}[54]$.

\section{$N$-acetylcysteine}

$\mathrm{N}$-acetylcysteine is an antioxidant and vasodilator that potentiates the effects of NO.

However, the results of studies on the efficacy of $\mathrm{N}$-acetylcysteine in the prevention of ICMrelated renal toxicity remain controversial. According to Liu et al., one of the pathophysiological hypotheses that could explain why the administration of antioxidant molecules is ineffective in the prevention of ICM-induced renal toxicity, is that ICM exert a direct toxicity on tubular cells, resulting in hypoxic and oxidative stress, and not the reverse [22]. Since the first randomized study conducted by Tepel et al. in 2000 [77], 37 studies and around 20 meta-analyses have been published on the subject. In total, only 15 of the 38 studies suggest that $\mathrm{N}$-acetylcysteine is effective in the prevention of ICM-related renal toxicity [74]. However, the small numbers of people studied, the heterogeneity of the populations, the use of small change in serum creatinine as the primary endpoint, and the absence of long-term follow-up, do not enable conclusions to be drawn on the efficacy of $\mathrm{N}$ acetylcysteine in this indication. These contradictory results were the reason for carrying out numerous meta-analyses. However, they also were unable to reach generally accepted conclusions, mainly due to methodological limitations [74]. In fact, these meta-analyses were even used as an example for a methodological critique of this type of study [78].

Nevertheless, due to the complete safety of the molecule, the KDIGO and the ERBP working group guidelines suggest the use of $\mathrm{N}$-acetylcysteine per os together with intravenous fluid loading [54,68], in contrast to the 2011 recommendations of the American College of Cardiology / American Heart Association / Society for Cardiovascular Angiography and Intervention [79] and the 2018 guidelines of the ESUR [69,70]. It is worth noting that the recently published well powered prospective randomized PRESERVE trial showed no benefit of N-acetylcysteine over placebo [76]. 
In addition to inhibiting Hydroxy-Methyl-Glutaryl Coenzyme A reductase, statins have "pleiotropic" properties including antioxidant, anti-inflammatory, and anti-thrombotic properties [80], and an anti-apoptotic effect. Furthermore, statins are able to decrease the vasoconstriction response to angiotensin II and to reduce the synthesis of endothelin, thereby preventing renal hypoperfusion and medullary hypoxia $[81,82]$. Despite certain methodological biases, several meta-analyses appear to confirm these observations (Table 5) [83-97]. A protective effect of statins was found in the general population [98-100] and particularly among people with renal impairment [57,97], especially if they had diabetes [97,101] and were "statin-naive". Although study results remain controversial [102-106], a high dose, or "loading dose" of statin appears to be more effective than a low dose in the prevention of ICM-induced nephrotoxicity, regardless of the type of statin studied (atorvastatin, simvastatin or rosuvastatin). However, the populations studied, the type of statin, dosage, rate of administration and associated hydration protocols were heterogeneous. In most cases, serum creatinine was measured only early on (48-72h), with no long term follow-up. The "target population", optimal agent, dosage and rate of administration are still to be determined. Statins are neither recommended by the 2018 guidelines of the ESUR [69,70], nor by the ACR [36], and nor by KDIGO [54]. In contrast, the European Society of Cardiology/European Association for Cardio-Thoracic Surgery guidelines suggest that "the implementation of high-dose statin before diagnostic catheterization should be considered as an additional preventive measure in patients without contraindications" [107].

\section{Other pharmacological agents}

Many other pharmacological agents have been studied, including ascorbic acid, calcium channel blockers, furosemide, prostaglandin analogs, endothelin agonists, adenosine antagonists, L-arginine, hypertonic mannitol, dopamine, and theophylline [108-110]. None of these treatments seem to be effective in the prevention of ICM-induced renal toxicity.

\section{Ischemic preconditioning}


Ischemic preconditioning is a non-pharmacological, non-invasive technique, first described in 1986 in dogs [111] and then in 1993 in humans [112]. This method consists of creating short sequences of ischemia/reperfusion, some time before the occurrence of prolonged ischemia, in order to "prepare" the cells against the risk of later ischemic damage. This technique relies on a ubiquitous endogenous cytoprotection mechanism, which is highly conserved across species [112]. Depriving cells of oxygen and nutrients induces on the one hand, stimulation of anaerobic glycolysis, and on the other, inhibition of oxidative phosphorylation [113]. After reperfusion, cell metabolism being slowed down, the massive intake of oxygen causes an "oxidative burst". Cell damage is caused by the release of a large quantity of ROS and proinflammatory cytokines. In response to ischemia, the cells slow down their metabolic activity and activate a number of cytoprotective mechanisms [113], which are often overwhelmed if the ischemia is prolonged, leading to cell death, resulting in acute tubular necrosis.

Ischemic preconditioning can be performed using a blood pressure cuff before administration of the ICM. The cuff is inflated for 5 minutes (ischemia), then deflated for 5 minutes (reperfusion), 4 cycles in a row. While studies on the efficacy of ischemic preconditioning seem to show cardiovascular [112,114] and renal [115,116] benefit before cardiac surgery studies conducted on the prevention of ICM-induced AKI are few, have involved less people, and their results remain controversial $[117,118]$.

\section{Renal-Guard $^{\circledR}$ System}

In 1999, Stevens et al. showed that the administration of a single dose of diuretic combined with hydration adapted to the volume of diuresis, limited the risk of ICM-induced nephropathy, and that urinary output greater than or equal to $150 \mathrm{~mL} / \mathrm{h}$ was associated with a reduction in renal medullary toxicity related to the administration of ICM [119]. The principle of the Renal-Guard® System or "controlled forced diuresis" is based on a technique in which a furosemide-induced increase in urinary output is immediately compensated by intravenous infusion of $0.9 \% \mathrm{NaCl}$ in order to avoid dehydration. The aim is to combine a potentially beneficial effect of furosemide with the maintenance of normal hydration. Furosemide, which inhibits the tubular Na-K-2Cl co-transporter is thought to limit epithelial ATP consumption and hence renal medullary hypoxia. This system requires a perfect adequacy between furosemide's diuretic effect and $\mathrm{NaCl}$ infusion rate. If the achieved increase in urinary volume is greater than its compensation by $0.9 \% \mathrm{NaCl}$ the risk of $\mathrm{AKI}$ is increased. Conversely, if the 
infusion rate is greater than urinary output, there is a risk of salt and water overload an eventually even pulmonary edema, as reported in some studies [120].

A recent meta-analysis has shown that the RenalGuard® System reduced the incidence of ICM-induced AKI in high-risk patients undergoing percutaneous coronary intervention or transcatheter aortic valve replacement [121]. While the results of this technique are interesting $[120,122]$ studies remain few in number and small in size, were not always randomized, and were mainly conducted in highly selected populations. Furthermore, to our knowledge, the effectiveness of this system has only been assessed with intra-arterial ICM administration. Its usefulness needs to be explored with intravenous ICM use as well. Finally, the device is invasive, probably expensive, and the therapeutic protocol should be refined to prevent hypovolemia and AKI risk. 


\section{Conclusion}

ICM-induced nephropathy is the third most common cause of AKI. It is the result of direct intrinsic toxicity of ICM for renal tubular epithelial and endothelial cells, the impairment of renal hemodynamics, and/or ICM administration modalities; all these mechanisms being very closely linked. There is no specific diagnostic biomarker or treatment. Preventive measures are therefore essential for limiting iatrogenic AKI. The risk-benefit ratio should be assessed before each examination using ICM. If the injection of ICM is necessary the volume, osmolality and viscosity of the ICM should be as low as possible. Nephrotoxic treatments should be discontinued and salt and water intake be sufficient. Correcting volume depletion remains the cornerstone of prevention. The use of antioxidants such as statins or $\mathrm{N}$ acetylcysteine may complement preventive measures, but should never replace a correct hydration status. Predicting the risk of ICM-induced AKI or persistent loss of kidney function following ICM injection remains very difficult. Current AKI definitions lump together heterogeneous phenotypes but in future, development of "biomarker signatures" and functional imaging techniques may help distinguish "hemodynamic AKI" from AKI related "tissue injury", and thus identify different phenotypes of patients for a better understanding of the pathophysiology and the development of new therapeutic approaches.

Disclosure: The authors have no conflict of interest to declare.

\section{Support / funding: None}

Author contributions: All authors researched the data, wrote the draft and made critical revision of the manuscript for important intellectual content. 
Legends of tables and figures

Table 1: Classification of intravenous iodinated contrast media. According to the American College of Radiology, Manual on contrast media, version 10.3, 2018 [36].

Table 2: Risk factors for nephrotoxicity associated with the administration of iodinated contrast media.

Table 3: Mehran risk score. SBP: systolic blood pressure. *NYHA : New York Heart Association functional classification, and/or history of pulmonary edema. Ht: hematocrit. eGFR: estimated Glomerular Filtration Rate. According to Mehran et al. J Am Coll Cardiol, $2004[50]$.

Table 4: Comparison of European Society of Urogenital Radiology (ESUR), American College of radiology (ACR), European renal Best Practice (ERBP) and Kidney Disease Improving Global Outcomes (KDIGO) guidelines. AKI: acute kidney injury; CKD: chronic kidney disease; eGFR: estimated glomerular filtration rate; ICM: iodinated contrast media; i.a: intra-arterial route; i.v: intra-venous route.

Table 5: Meta-analyses of randomized controlled studies on the use of statins in the prevention of iodinated contrast media-induced renal toxicity, following angiography.*Only randomized studies evaluated by this meta-analysis have been included in the table.

Figure 1: Pathophysiology of renal damage associated with the administration of iodinated contrast media. ZO-1: Zonula occludens-1, TAL: Thick ascending limb of the loop of Henle, NKCC2: Na-K-Cl cotransporter, NO: nitric oxide, CKD: chronic kidney disease, RBC: red blood cell.

Figure 2: Iodinated contrast media are tri-iodinated benzene derivatives. Four families of iodinated contrast media: tri-iodinated ionic monomer, tri-iodinated nonionic monomer, hexaiodinated ionic dimer, hexa-iodinated nonionic dimer. The cation can be a sodium ion or meglumine. 


\section{References}

1. Stacul F, van der Molen AJ, Reimer P, et al. Contrast Media Safety Committee of European Society of Urogenital Radiology (ESUR). Contrast induced nephropathy: updated ESUR contrast media safety committee guidelines. Eur Radiol. 21(2011) 2527-41.

2. Nash K, Hafeez A, Hou S. Hospital-acquired renal insufficiency. Am J Kidney Dis. 39 (2002) 930-6.

3. McCullough PA. Contrast-induced acute kidney injury. J Am Coll Cardiol. 51 (2008) 1419-28.

4. Jabara R, Gadesam RR, Pendyala LK, et al. Impact of the definition utilized on the rate of contrast-induced nephropathy in percutaneous coronary intervention. Am J Cardiol. 103 (2009) 1657-62.

5. Mitchell AM, Jones AE, Tumlin JA, Kline JA. Incidence of contrast-induced nephropathy after contrast-enhanced computed tomography in the outpatient setting. Clin J Am Soc Nephrol. 5 (2010) 4-9.

6. Wilhelm-Leen E, Montez-Rath ME, Chertow G. Estimating the Risk of RadiocontrastAssociated Nephropathy. J Am Soc Nephrol. 28 (2017) 653-9.

7. McCullough PA, Adam A, Becker CR, et al. CIN Consensus Working Panel. Risk prediction of contrast-induced nephropathy. Am J Cardiol. 98 (2006) 27-36.

8. Coca SG, Singanamala S, Parikh CR. Chronic kidney disease after acute kidney injury: a systematic review and meta-analysis. Kidney Int. 81 (2012) 442-8.

9. Rewa O, Bagshaw SM· Acute kidney injury-epidemiology, outcomes and economics. Nat Rev Nephrol. 10 (2014) 193-207.

10. Levy EM, Viscoli CM, Horwitz RI. The effect of acute renal failure on mortality. A cohort analysis. JAMA. 275 (1996) 1489-94.

11. Rihal CS, Textor SC, Grill DE, et al. Incidence and prognostic importance of acute renal failure after percutaneous coronary intervention. Circulation. 105 (2002) 2259-64.

12. Solomon R, Dauerman HL. Contrast-induced acute kidney injury. Circulation. 122 (2010) 2451-5.

13. Gruberg L, Mintz GS, Mehran R, et al. The prognostic implications of further renal function deterioration within $48 \mathrm{~h}$ of interventional coronary procedures in patients with preexistent chronic renal insufficiency. J Am Coll Cardiol. 36 (2000) 1542-8.

14. McCullough PA, Wolyn R, Rocher LL, Levin RN, O'Neill WW. Acute renal failure after coronary intervention: incidence, risk factors, and relationship to mortality. Am J Med. 103 (1997) 368-75. 
15. McCullough PA. Epidemiology of contrast induced nephropathy. Rev Cardiovasc Med. 4 (2003) 53-9

16. Persson PB, Tepel M. Contrast medium-induced nephropathy: The pathophysiology. Kidney Int. 69 (2006) S8-S10.

17. Seeliger E, Sendeski M, Rihal CS, Persson PB. Contrast-induced kidney injury: mechanisms, risk factors, and prevention. Eur Heart J. 33 (2012) 2007-15.

18. Romano G, Briguori C, Quintavalle C, et al. Contrast agents and renal cell apoptosis. Eur Heart J. 29 (2008) 2569-76.

19. Hardiek K, Katholi RE, Ramkumar V, Deitrick C. Proximal tubule cell response to radiographic contrast media. Am J Physiol Renal Physiol. 280 (2001) F61-F70.

20. Sendeski MM. Pathophysiology of renal tissue damage by iodinated contrast media. Clin Exp Pharmacol Physiol. 38 (2011) 292-9.

21. Quintavalle C, Brenca M, De Micco F, et al. In vivo and in vitro assessment of pathways involved in contrast media-induced renal cells apoptosis. Cell Death Dis. 2 (2011) e155.

22. Liu ZZ, Schmerbach K, Lu Y, et al. Iodinated contrast media cause direct tubular cell damage, leading to oxidative stress, low nitric oxide, and impairment of tubuloglomerular feedback. Am J Physiol Renal Physiol. 306 (2014) F864-72.

23. Schick CS, Haller C. Comparative cytotoxicity of ionic and non-ionic radiocontrast agents on MDCK cell monolayers in vitro. Nephrol Dial Transplant. 14 (1999) 342-7.

24. Christiansen C. X-Ray contrast media: An overview. Toxicology. 209 (2005) 185-7.

25. Hizóh I, Sträter J, Schick CS, Kübler W, Haller C. Radiocontrast-induced DNA fragmentation of renal tubular cells in vitro: role of hypertonicity. Nephrol Dial Transplant. 13 (1998) 911-8.

26. Sendeski MM, Persson AB, Liu ZZ, et al. Iodinated contrast media cause endothelial damage leading to vasoconstriction of human and rat vasa recta. Am J Physiol Renal Physiol. 303 (2012) F1592-8.

27. Ortiz PA, Garvin JL. Interaction of $\mathrm{O} 2$ and NO in the thick ascending limb. Hypertension. 39 (2002) 591-6.

28. Ortiz PA, Garvin JL. Superoxide stimulates $\mathrm{NaCl}$ absorption by the thick ascending limb. Am J Physiol Renal Physiol. 283 (2002) 957-62.

29. Juncos R, Garvin JL. Superoxide enhances Na-K-2Cl co-transporter activity in the thick ascending limb. Am J Physiol Renal Physiol. 288 (2005) 982-7.

30. Silva GB, Ortiz PA, Hong NJ, Garvin JL. Superoxide stimulates $\mathrm{NaCl}$ absorption in the thick ascending limb via activation of protein kinase C. Hypertension. 48 (2006) 467-72. 
31. Heyman SN, Rosen S, Rosenberger C. Renal parenchymal hypoxia, hypoxia adaptation, and the pathogenesis of radiocontrast nephropathy. Clin J Am Soc Nephrol. 3 (2008) 288-96.

32. Heyman SN, Rosen S, Khamaisi M, Idée JM, Rosenberger C. Reactive oxygen species and the pathogenesis of radiocontrast-induced nephropathy. Invest Radiol. 45 (2010) 188-95.

33. Jost G, Lengsfeld P, Lenhard DC, Pietsch H, Hütter J, Sieber MA. Viscosity of iodinated contrast agents during renal excretion. Eur J Radiol. 80 (2011) 373-7.

34. Aspelin P, Stacul F, Thomsen HS, Morcos SK, van der Molen AJ; Members of the Contrast Media Safety Committee of the European Society of Urogenital Radiology (ESUR). Effects of iodinated contrast media on blood and endothelium. Eur Radiol. 16 (2006) 1041-9.

35. Brezis M, Rosen S. Hypoxia of the renal medulla -its implications for disease. $N$ Engl J Med. 332 (1995) 647-55.

36. American College of Radiology committee on drugs and contrast media, ACR manual on contrast media, version 10.3, 2018 https://www.acr.org/-/media/ACR/Files/ClinicalResources/Contrast_Media.pdf

37. Barrett BJ, Carlisle EJ. Metaanalysis of the relative nephrotoxicity of high- and lowosmolality iodinated contrast media. Radiology 188 (1993) 171-8.

38. Liss P, Persson PB, Hansell P, Lagerqvist B. Renal failure in 57925 patients undergoing coronary procedures using iso-osmolar or low-osmolar contrast media. Kidney Int. 70 (2006) 1811-7.

39. McCullough PA, Bertrand ME, Brinker JA, Stacul F. A meta-analysis of the renal safety of isosmolar iodixanol compared with low-osmolar contrast media. J Am Coll Cardiol. 48 (2006) 692-9.

40. Reed M, Meier P, Tamhane UU, Welch KB, Moscucci M, Gurm HS. The relative renal safety of iodixanol compared with low-osmolar contrast media: a meta-analysis of randomized controlled trials. JACC Cardiovasc Interv 2 (2009) 645-54.

41. Eng J, Wilson RF, Subramaniam RM, et al. Comparative Effect of Contrast Media Type on the Incidence of Contrast-Induced Nephropathy: A Systematic Review and Meta-analysis. Ann Intern Med. 164 (2016) 417-24.

42. van der Molen AJ, Reimer P, Dekkers IA, et al. Post-contrast acute kidney injury - Part 1: Definition, clinical features, incidence, role of contrast medium and risk factors: Recommendations for updated ESUR Contrast Medium Safety Committee guidelines. Eur Radiol. 28 (2018) 2845-2855.

43. Toprak O. Risk markers for contrast-induced nephropathy. Am J Med Sci. 334 (2007) 283-90.

44. Balemans CE, Reichert LJ, van Schelven BI, van den Brand JA, Wetzels JF. Epidemiology of contrast material-induced nephropathy in the era of hydration. Radiology. 263 (2012) 706-13. 
45. Solomon R. Contrast-induced acute kidney injury: is there a risk after intravenous contrast? Clin J Am Soc Nephrol. 3 (2008) 1242-3.

46. Kooiman J, Le Haen PA, Gezgin G, et al. Contrast-induced acute kidney injury and clinical outcomes after intra-arterial and intravenous contrast administration: risk comparison adjusted for patient characteristics by design. Am Heart J. 165 (2013) 793-99.

47. McDonald JS, Leake CB, McDonald RJ, et al. Acute Kidney injury after intravenous versus intra-arterial contrast material administration in a paired cohort. Invest Radiol. 51 (2016) 804-809.

48. Laskey WK, Jenkins C, Selzer F, et al. NHLBI Dynamic Registry Investigators. Volumeto-creatinine clearance ratio: a pharmacokinetically based risk factor for prediction of early creatinine increase after percutaneous coronary intervention. J Am Coll Cardiol. 50 (2007) 584-90.

49. Nyman U, Bjork J, Aspelin P, Marenzi G. Contrast medium dose-to-GFR ratio: A measure of systemic exposure to predict contrast-induced nephropathy after percutaneous coronary intervention. Acta Radiol. 49 (2008) 658-67.

50. Mehran R, Aymong ED, Nikolsky E, et al. A simple risk score for prediction of contrastinduced nephropathy after percutaneous coronary intervention: development and initial validation. J Am Coll Cardiol. 44 (2004) 1393-9.

51. McDonald JS, McDonald RJ, Comin J, et al. Frequency of acute kidney injury following intravenous contrast medium administration: a systematic review and meta-analysis.

Radiology. 267 (2013) 119-28.

52. McDonald JS, McDonald RJ, Carter RE, Katzberg RW, Kallmes DF, Williamson EE. Risk of intravenous contrast material-mediated acute kidney injury: a propensity scorematched study stratified by baseline-estimated glomerular filtration rate. Radiology 271 (2014) 65-73.

53. Silver SA, Shah PM, Chertow GM, Harel S, Wald R, Harel Z. Risk prediction models for contrast induced nephropathy: systematic review. BMJ 351 (2015) h4395.

54. Kidney Disease: Improving Global Outcomes (KDIGO) Acute Kidney Injury Work Group. KDIGO Clinical Practice Guideline for Acute Kidney Injury. Kidney Int Suppl. 2 (2012) 1-138.

55. Thomsen HS, Morcos SK; Members of Contrast Media Safety Committee of European Society of Urogenital Radiology (ESUR). In which patients should serum creatinine be measured before iodinated contrast medium administration? Eur Radiol. 15 (2005) 749-54.

56. Briguori C, Visconti G, Rivera NV, et al. Cystatin C and contrast-induced acute kidney injury. Circulation 121 (2010) 2117-22.

57. Quintavalle C, Fiore D, De MiccoF, et al. Impact of a high loading dose of atorvastatin on contrast-induced acute kidney injury. Circulation. 126 (2012) 3008-16. 
58. Newman DJ, Thakkar H, Edwards RG, et al. Serum cystatin C measured by automated immunoassay: a more sensitive marker of changes in GFR than serum creatinine. Kidney Int. 47 (1995) 312-8.

59. Dharnidharka VR, Kwon C, Stevens G. Serum cystatin C is superior to serum creatinine as a marker of kidney function: a meta-analysis. Am J Kidney Dis. 40 (2002) 221-6.

60. Rickli H, Benou K, Ammann P, et al. Time course of serial cystatin C levels in comparison with serum creatinine after application of radiocontrast media. Clin Nephrol. 61 (2004) $98-102$.

61. Solomon RJ, Mehran R, Natarajan MK, et al. Contrast-induced nephropathy and longterm adverse events: cause and effect? Clin J Am Soc Nephrol. 4 (2009) 1162-9.

62. Lim AI, Tang SC, Lai KN, Leung JC. Kidney injury molecule-1: more than just an injury marker of tubular epithelial cells? J Cell Physiol. 228 (2013) 917-24.

63. Singer E, Markó L, Paragas N, et al. Neutrophil gelatinase-associated lipocalin: pathophysiology and clinical applications. Acta Physiol (Oxf). 207 (2013) 663-72.

64. Li LP, Lu J, Zhou Y, et al. Evaluation of intrarenal oxygenation in iodinated contrastinduced acute kidney injury-susceptible rats by blood oxygen level-dependent magnetic resonance imaging. Invest Radiol. 49 (2014) 403-10.

65. Deray G. Dialysis and iodinated contrast media. Kidney Int Suppl. 100 (2006) S25-9.

66. Lehnert T, Keller E, Gondolf K, Schäffner T, Pavenstädt H, Schollmeyer P. Effect of haemodialysis after contrast medium administration in patients with renal insufficiency. Nephrol Dial Transplant. 13 (1998) 358-62.

67. Vogt B, Ferrari P, Schönholzer C, et al. Prophylactic hemodialysis after radiocontrast media in patients with renal insufficiency is potentially harmful. Am J Med. 111 (2001) 692-8.

68. The ad-hoc working group of ERBP. A European Renal Best Practice (ERBP) position statement on the Kidney Disease Improving Global Outcomes (KDIGO) clinical practice guidelines on acute kidney injury: Part 1: Definitions, conservative management and contrastinduced nephropathy. Nephrol Dial Transplant. 27 (2012) 4263-72.

69. van der Molen AJ, Reimer P, Dekkers IA, et al. Post-contrast acute kidney injury. Part 2: risk stratification, role of hydration and other prophylactic measures, patients taking metformin and chronic dialysis patients: Recommendations for updated ESUR Contrast Medium Safety Committee guidelines. Eur Radiol. 28 (2018) 2856-2869.

70. European Society of Urogenital Radiology, Contrast-Media Guidelines 10.0, 2018. http://www.esur.org/esur-guidelines/

71. Weisbord SD, Palevsky PM. Prevention of contrast-induced nephropathy with volume expansion. Clin J Am Soc Nephrol. 3 (2008) 273-80. 
72. Stacul F, Adam A, Becker CR, et al. CIN Consensus Working Panel. Strategies to reduce the risk of contrast-induced nephropathy. Am J Cardiol. 98 (2006) 59K-77K.

73. Merten GJ, Burgess WP, Gray LV, et al. Prevention of contrast-induced nephropathy with sodium bicarbonate: a randomized controlled trial. JAMA. 291 (2004) 2328-34.

74. Weisbord SD, Gallagher M, Kaufman J, et al. Prevention of contrast-induced AKI: a review of published trials and the design of the prevention of serious adverse events following angiography (PRESERVE) trial. Clin J Am Soc Nephrol. 8 (2013) 1618-31.

75. NijssenEC, Rennenberg RJ, Nelemans PJ, et al. Prophylactic hydration to protect renal function from intravascular iodinated contrast material in patients at high risk of contrastinduced nephropathy (AMACING): a prospective, randomised, phase 3, controlled, openlabel, non-inferiority trial. Lancet. 389 (2017) 1312-22.

76. Weisbord SD, Gallagher M, Jneid H, et al. PRESERVE Trial Group. Outcomes after Angiography with Sodium Bicarbonate and Acetylcysteine. N Engl J Med. 378 (2018) 603614.

77. Tepel M, van der Giet M, Schwarzfeld C, Laufer U, Liermann D, Zidek W. Prevention of radiographic-contrast-agent-induced reductions in renal function by acetylcysteine. $N$ Engl $\mathrm{J}$ Med. 343 (2000) 180-4.

78. Vaitkus PT, Brar C. N-acetylcysteine in the prevention of contrast-induced nephropathy: publication bias perpetuated by meta-analyses. Am Heart J. 153 (2007) 275-80.

79. Levine GN, Bates ER, Blankenship JC, et al. 2011 ACCF/AHA/SCAI Guideline for Percutaneous Coronary Intervention: a report of the American College of Cardiology Foundation/American Heart Association Task Force on Practice Guidelines and the Society for Cardiovascular Angiography and Interventions. Circulation. 124 (2011) e574-651

80. Profumo E, Buttari B, Saso L, Rigano R. Pleiotropic effects of statins in atherosclerotic disease: focus on the antioxidant activity of atorvastatin. Curr Top Med Chem. 14 (2014) 2542-51.

81. Bonetti PO, Lerman LO, Napoli C, Lerman A. Statin effects beyond lipid lowering - are they clinically relevant? Eur Heart J. 24 (2003) 225-48.

82. Wierzbicki AS, Poston R, Ferro A. The lipid and non-lipid effects of statins. Pharmacol Ther. 99 (2003) 95-112.

83. Zhang BC, Li WM, Xu YW. High-dose statin pretreatment for the prevention of contrastinduced nephropathy: a meta-analysis. Can J Cardiol. 27 (2011) 851-8.

84. Zhou Y, Yuan WJ, Zhu N, Wang L. Short-term, high-dose statins in the prevention of contrast-induced nephropathy: a systematic review and meta-analysis. Clin Nephrol. 76 (2011) 475-83. 
85. Li Y, Liu Y, Fu L, Mei C, Dai B. Efficacy of short-term high-dose statin in preventing contrast-induced nephropathy: a meta-analysis of seven randomized controlled trials. PLoS One. 7 (2012) e34450.

86. Giacoppo D, Capodanno D, Capranzano P, Aruta P, Tamburino C. Meta-analysis of randomized controlled trials of pre-procedural statin administration for reducing contrastinduced acute kidney injury in patients undergoing coronary catheterization. Am J Cardiol. 114 (2014) 541-8.

87. Lee JM, Park J, Jeon KH, et al. Efficacy of short-term high-dose statin pretreatment in prevention of contrast-induced acute kidney injury: updated study-level meta-analysis of 13 randomized controlled trials. PLoS One. 9 (2014) e111397.

88. Ukaigwe A, Karmacharya P, Mahmood M, et al. Meta-analysis on efficacy of statins for prevention of contrast-induced acute kidney injury in patients undergoing coronary angiography. Am J Cardiol. 114 (2014) 1295-302.

89. Marenzi G, Cosentino N, Werba JP, Tedesco CC, Veglia F, Bartorelli AL. A metaanalysis of randomized controlled trials on statins for the prevention of contrast-induced acute kidney injury in patients with and without acute coronary syndromes. Int J Cardiol. 183 (2015) 47-53.

90. Wu H, Li D, Fang M, Han H, Wang H. Meta-analysis of short-term high versus low doses of atorvastatin preventing contrast-induced acute kidney injury in patients undergoing coronary angiography/percutaneous coronary intervention. J Clin Pharmacol. 55 (2015) 12331.

91. Liu YH, Liu Y, Duan CY, et al. Statins for the prevention of contrast-induced nephropathy after coronary angiography / percutaneous interventions: a meta-analysis of randomized controlled trials. J Cardiovasc Pharmacol Ther. 20 (2015) 181-92.

92. Takagi H, Umemoto T. A meta-analysis of randomized trials for effects of periprocedural atorvastatin on contrast-induced nephropathy. Int J Cardiol. 153 (2011) 323-5.

93. Yang Y, Wu YX, Hu YZ. Rosuvastatin treatment for preventing contrast-induced acute kidney injury after cardiac catheterization: a meta-analysis of randomized controlled trials. Medicine (Baltimore). 94 (2015) e1226.

94. Cheungpasitporn W, Thongprayoon C, Kittanamongkolchai W, et al. Periprocedural effects of statins on the incidence of contrast-induced acute kidney injury: a systematic review and meta-analysis of randomized controlled trials. Ren Fail. 37 (2015) 664-71.

95. Wang N, Qian P, Yan TD, Phan K. Periprocedural effects of statins on the incidence of contrast-induced acute kidney injury: A systematic review and trial sequential analysis. Int $J$ Cardiol. 206 (2016) 143-52.

96. Zografos T, Oikonomou E, Siasos G, et al. High-dose statin therapy is effective at preventing the development of contrast-induced nephropathy in patients undergoing percutaneous coronary intervention for acute coronary syndromes: a meta-analysis. J Am Coll Cardiol. 67(13) (2016), Supplement, p173 (abstract). 
97. Liang M, Yang S, Fu N. Efficacy of short-term moderate or high-dose rosuvastatin in preventing contrast-induced nephropathy: a meta-analysis of 15 randomized controlled trials. Medicine (Baltimore). 96 (2017) e7384.

98. Xinwei J, Xianghua F, Jing Z, et al. Comparison of usefulness of simvastatin $20 \mathrm{mg}$ versus $80 \mathrm{mg}$ in preventing contrast-induced nephropathy in patients with acute coronary syndrome undergoing percutaneous coronary intervention. Am J Cardiol. 104 (2009) 519-24.

99. Patti G, Ricottini E, Nusca A, et al. Short-term, high-dose atorvastatin pretreatment to prevent contrast-induced nephropathy in patients with acute coronary syndromes undergoing percutaneous coronary intervention (from the ARMYDA-CIN [Atorvastatin for Reduction of Myocardial Damage during Angioplasty-contrast-Induced Nephropathy] Trial. Am J Cardiol. 108 (2011) 1-7.

100. Leoncini M, Toso A, Maioli M, Tropeano F, Villani S, Bellandi F. Early high-dose rosuvastatin for contrast-induced nephropathy prevention in acute coronary syndrome: Results from the PRATO-ACS Study (Protective Effect of Rosuvastatin and Antiplatelet Therapy On contrast-induced acute kidney injury and myocardial damage in patients with Acute Coronary Syndrome). J Am Coll Cardiol. 63 (2014) 71-9.

101. Han Y, Zhu G, Han L, et al. Short-term rosuvastatin therapy for prevention of contrastinduced acute kidney injury in patients with diabetes and chronic kidney disease. J Am Coll Cardiol. 63 (2014) 62-70.

102. Jo SH, Koo BK, Park JS, et al. Prevention of radiocontrast medium-induced nephropathy using short-term high-dose simvastatin in patients with renal insufficiency undergoing coronary angiography (PROMISS) trial - a randomized controlled study. Am Heart J. 155 (2008) 499.e1-8.

103. Toso A, Maioli M, Leoncini M, et al. Usefulness of atorvastatin $(80 \mathrm{mg})$ in prevention of contrast-induced nephropathy in patients with chronic renal disease. Am J Cardiol. 105 (2010) 288-92.

104. Zhang L, Zhang L, Lu Y, et al. Efficacy of statin pretreatment for the prevention of contrast-induced nephropathy: a meta-analysis of randomised controlled trials. Int J Clin Pract. 65 (2011) 624-30.

105. Pappy R, Stavrakis S, Hennebry TA, Abu-Fadel MS. Effect of statin therapy on contrastinduced nephropathy after coronary angiography: a meta-analysis. Int J Cardiol. 151 (2011) 348-53.

106. Zhang T, Shen LH, Hu LH, He B. Statins for the prevention of contrast-induced nephropathy: a systematic review and meta-analysis. Am J Nephrol. 33 (2011) 344-51.

107. Authors/Task Force members, 2014 ESC/EACTS Guidelines on myocardial revascularization: The Task Force on Myocardial Revascularization of the European Society of Cardiology (ESC) and the European Association for Cardio-Thoracic Surgery (EACTS) Developed with the special contribution of the European Association of Percutaneous Cardiovascular Interventions (EAPCI). Eur Heart J. 35 (2014) 2541-619. 
108. Solomon R, Werner C, Mann D, D'Elia J, Silva P. Effects of saline, mannitol, and furosemide to prevent acute decreases in renal function induced by radiocontrast agents. $N$ Engl J Med. 331 (1994) 1416-20.

109. Dussol B, Morange S, Loundoun A, Auquier P, Berland Y. A randomized trial of saline hydration to prevent contrast nephropathy in chronic renal failure patients. Nephrol Dial Transplant. 21 (2006) 2120-6.

110. Majumdar SR, Kjellstrand CM, Tymchak WJ, Hervas-Malo M, Taylor DA, Teo KK. Forced euvolemic diuresis with mannitol and furosemide for prevention of contrast-induced nephropathy in patients with CKD undergoing coronary angiography: a randomized controlled trial. Am J Kidney Dis. 54 (2009) 602-9.

111. Murry CE, Jennings RB, Reimer KA. Preconditioning with ischemia: a delay of lethal cell injury in ischemic myocardium. Circulation. 74 (1986) 1124-36.

112. Kharbanda RK, Nielsen TT, Redington AN. Translation of remote ischaemic preconditioning into clinical practice. Lancet. 374 (2009) 1557-65.

113. Weinberg JM. The cell biology of ischemic renal injury. Kidney Int. 39 (1991) 476-500.

114. Walsh SR, Tang TY, Kullar P, Jenkins DP, Dutka DP, Gaunt ME. Ischaemic preconditioning during cardiac surgery: systematic review and meta-analysis of perioperative outcomes in randomized clinical trials. Eur J Cardiothorac Surg. 34 (2008) 985-94.

115. Zarbock A, Kellum JA. Remote Ischemic Preconditioning and Protection of the Kidney - A Novel Therapeutic Option. Crit Care Med. 44 (2016) 607-16.

116. Zarbock A, Kellum JA, Van Aken H, et al. Long-term Effects of Remote Ischemic Preconditioning on Kidney Function in High-risk Cardiac Surgery Patients: Follow-up Results from the Renal RIP Trial. Anesthesiology. 126 (2017) 787-798.

117. Er F, Nia AM, Dopp H, et al. Ischemic preconditioning for prevention of contrast medium-induced nephropathy: randomized pilot Ren Pro Trial (Renal Protection Trial). Circulation 126 (2012) 296-303.

118. Menting TP, Sterenborg TB, de Waal Y, et al. Remote Ischemic Preconditioning To Reduce Contrast-Induced Nephropathy: A Randomized Controlled Trial. Eur J Vasc Endovasc Surg. 50 (2015) 527-32.

119. Stevens MA, McCullough PA, Tobin KJ, et al. A prospective randomized trial of prevention measures in patients at high risk for contrast nephropathy: results of the P.R.I.N.C.E. Study. Prevention of Radiocontrast Induced Nephropathy Clinical Evaluation. J Am Coll Cardiol. 33 (1999) 403-11.

120. Briguori C, Visconti G, Focaccio A, et al. REMEDIAL II Investigators. Renal Insufficiency After Contrast Media Administration Trial II (REMEDIALII): Renal Guard System in high-risk patients for contrast-induced acute kidney injury. Circulation. 124 (2011) 1260-9. 
121. Putzu A, BoscoloBerto M, Belletti A, et al. Prevention of contrast-induced acute kidney injury by furosemide with matched hydration in patients undergoing interventional procedures: a systematic review and meta-analysis of randomized trials. JACC Cardiovasc Interv. 10 (2017) 355-363.

122. Marenzi G, Ferrari C, Marana I, et al. Prevention of contrast nephropathy by furosemide with matched hydration: the MYTHOS (Induced Diuresis With Matched Hydration Compared to Standard Hydration for Contrast Induced Nephropathy Prevention) trial. JACC Cardiovasc Interv. 5 (2012) 90-7. 
Table 1: Classification of intravascular iodinated contrast media. According to the American College of Radiology, Manual on contrast media, version 10.3, 2018 [36].

\begin{tabular}{|c|c|c|c|c|c|c|}
\hline & & $\begin{array}{l}\text { International non- } \\
\text { proprietary name } \\
\text { (mg contrast/mL) }\end{array}$ & $\begin{array}{l}\text { Commercial } \\
\text { name }\end{array}$ & $\begin{array}{l}\text { Concentration } \\
\text { of iodine } \\
(\mathrm{mg} / \mathrm{mL})\end{array}$ & $\begin{array}{l}\text { Osmolality } \\
(\mathrm{mOsm} / \mathrm{kg} \\
\left.\mathrm{H}_{2} \mathrm{O}\right)\end{array}$ & $\begin{array}{l}\text { Viscosity } \\
\text { 37 }{ }^{\circ} \mathbf{C} \\
\text { (mPa.s) }\end{array}$ \\
\hline High osmolality & Tri-iodinated & Diatrizoate 760 & MD-76 & 370 & 1551 & 10.5 \\
\hline $1000-2000$ & ionic monomers & Iothalamate 600 & Conray & 282 & 1400 & 4 \\
\hline $\mathrm{mOsmol} / \mathrm{kg} \mathrm{H}_{2} \mathrm{O}$ & & Iothalamate 430 & Conray 43 & 202 & 1000 & 2 \\
\hline \multirow{22}{*}{$\begin{array}{l}\text { Low osmolality } \\
300-800 \\
\text { mOsmol/kg } \mathrm{H}_{2} \mathrm{O}\end{array}$} & $\begin{array}{l}\text { Tri-iodinated } \\
\text { ionic monomers }\end{array}$ & Iothalamate 300 & Conray 30 & 141 & 600 & 1.5 \\
\hline & Hexa-iodinated & Iodipamide 520 & Cholografin & 257 & 664 & 5.6 \\
\hline & ionic dimers & Ioxaglate 589 & Hexabrix & 320 & $\approx 600$ & 7.5 \\
\hline & Tri-iodinated & Iopamidol 755 & Isovue 370 & 370 & 796 & 9.4 \\
\hline & nonionic & Iopamidol 612 & Isovue 300 & 300 & 616 & 4.7 \\
\hline & monomers & Iopamidol 510 & Isovue 250 & 250 & 524 & 3.0 \\
\hline & & Iopamidol 408 & Isovue 200 & 200 & 413 & 2.0 \\
\hline & & Iohexol 755 & Omnipaque 350 & 350 & 844 & 10.4 \\
\hline & & Iohexol 647 & Omnipaque 300 & 300 & 672 & 6.3 \\
\hline & & Iohexol 518 & Omnipaque 240 & 240 & 520 & 3.4 \\
\hline & & Iohexol 388 & Omnipaque 180 & 180 & 408 & 2.0 \\
\hline & & Iohexol 302 & Omnipaque 140 & 140 & 322 & 1.5 \\
\hline & & Ioxilan 727 & Oxilan 350 & 350 & 721 & 8.1 \\
\hline & & Ioxilan 623 & Oxilan 300 & 300 & 610 & 5.1 \\
\hline & & Ioversol 740 & Optiray 350 & 350 & 792 & 9.0 \\
\hline & & Ioversol 680 & Optiray 320 & 320 & 702 & 5.8 \\
\hline & & Ioversol 640 & Optiray 300 & 300 & 651 & 5.5 \\
\hline & & Ioversol 509 & Optiray 240 & 240 & 502 & 3.0 \\
\hline & & iopromide & Ultravist 370 & 370 & 774 & 10.0 \\
\hline & & iopromide & Ultravist 300 & 300 & 607 & 4.9 \\
\hline & & iopromide & Ultravist 240 & 240 & 483 & 2.8 \\
\hline & & iopromide & Ultravist 150 & 150 & 328 & 1.5 \\
\hline \multirow{2}{*}{$\begin{array}{l}\text { Iso-osmolality } \\
290 \mathrm{mOsmol} / \mathrm{kg} \mathrm{H}_{2} \mathrm{O}\end{array}$} & Hexa-iodinated & Iodixanol 652 & Visipaque 320 & 320 & 290 & 11.8 \\
\hline & nonionic dimers & Iodixanol 550 & Visipaque 270 & 270 & 290 & 6.3 \\
\hline
\end{tabular}


Table 2: Risk factors for nephrotoxicity associated with the administration of iodinated contrast media.

\begin{tabular}{|l|}
\hline Patient related risk factors \\
\hline Preexisting chronic kidney disease \\
Diabetes mellitus \\
Old age \\
Dehydration / hypovolemia: sepsis, diuretic treatment, low cardiac output... \\
Hemodynamic instability \\
Proteinuria \\
Myeloma \\
Anemia \\
Low serum albumin concentration $(<35 \mathrm{~g} / \mathrm{L})$ \\
\hline Iodinated contrast media related risk factors \\
\hline Intra-arterial injection \\
High osmolality \\
High viscosity \\
Injected volume $>100 \mathrm{~mL}$ \\
Multiple injections, short time between injections $(<72 \mathrm{~h})$ \\
\hline Nephrotoxic drugs \\
\hline Non steroid anti-inflammatory drugs \\
Aminoglycoside antibiotics \\
Calcineurin inhibitors \\
$\ldots$ \\
\hline
\end{tabular}


Table 3: Mehran risk score. SBP: systolic blood pressure. *NYHA: New York Heart Association functional classification, and/or history of pulmonary edema. Ht: hematocrit, eGFR: estimated Glomerular Filtration Rate. According to Mehran et al. J Am Coll Cardiol, $2004[50]$.

\begin{tabular}{|l|c|}
\hline Risk factors & Score \\
\hline Hypotension (SBP $<80 \mathrm{mmHg}$ ) & 5 \\
\hline Intra-aortic balloon pump & 5 \\
\hline Congestive heart failure (NYHA III or IV)* & 5 \\
\hline Age $>75$ years & 4 \\
\hline Anemia $(\mathrm{Ht}<39 \%$ in man $;<36 \%$ in woman) & 3 \\
\hline Diabetes & 3 \\
\hline Volume of injected contrast media & 1 for each $100 \mathrm{~mL}$ \\
\hline Serum creatinine concentration $>1.5 \mathrm{mg} / \mathrm{dL}$ & 4 \\
& 2 if eGFR $=40-60$ \\
OR eGFR $<60 \mathrm{~mL} / \mathrm{min} / 1.73 \mathrm{~m}^{2}$ & 4 if eGFR $=20-40$ \\
& 6 if eGFR $<20$ \\
\hline
\end{tabular}

\begin{tabular}{|l|c|c|c|}
\hline & Risk score & $\begin{array}{c}\text { Risk of contrast } \\
\text { induced } \\
\text { nephropathy }\end{array}$ & $\begin{array}{c}\text { Risk } \\
\text { of dialysis }\end{array}$ \\
\hline Low & $\leq 5$ & $7.5 \%$ & $0.04 \%$ \\
\hline Moderate & $6-10$ & $14 \%$ & $0.12 \%$ \\
\hline High & $11-15$ & $26.1 \%$ & $1.09 \%$ \\
\hline Very high & $\geq 16$ & $57.3 \%$ & $12.6 \%$ \\
\hline
\end{tabular}

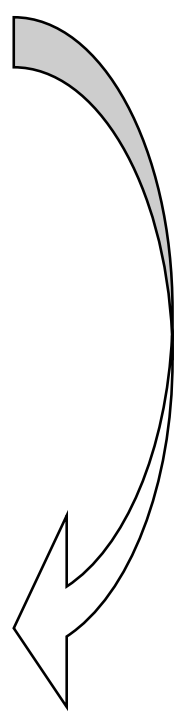


Table 4: Comparison of European Society of Urogenital Radiology (ESUR), American College of radiology (ACR), European renal Best Practice (ERBP) and Kidney Disease Improving Global Outcomes (KDIGO) guidelines. AKI: acute kidney injury; CKD: chronic kidney disease; eGFR: estimated glomerular filtration rate; ICM: iodinated contrast media; i.a: intra-arterial route; i.v: intra-venous route.

\begin{tabular}{|c|c|c|c|c|}
\hline & $\begin{array}{c}\text { European Society of Urogenital } \\
\text { Radiology } 2018\end{array}$ & $\begin{array}{l}\text { American College of } \\
\text { Radiology } 2018\end{array}$ & $\begin{array}{l}\text { European Renal } \\
\text { Best Practice } 2012\end{array}$ & $\begin{array}{l}\text { Kidney Disease Improving } \\
\text { Global Outcomes } 2012\end{array}$ \\
\hline \multicolumn{5}{|c|}{ 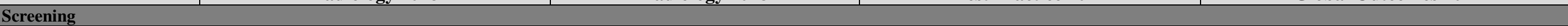 } \\
\hline & $\begin{array}{l}\text { Either in all patients, or in patients who have a } \\
\text { history of renal disease (eGFR }<60 \\
\mathrm{ml} / \mathrm{min} / 1.73 \mathrm{~m} 2 \text { ), kidney surgery, proteinuria, } \\
\text { hypertension, hyperuricemia or diabetes } \\
\text { mellitus. }\end{array}$ & $\begin{array}{l}\text { Age }>60 \text {, history of renal disease } \\
\text { (dialysis, kidney transplant, single } \\
\text { kidney, renal cancer, renal surgery), } \\
\text { history of hypertension requiring } \\
\text { medical therapy, history of diabetes } \\
\text { mellitus, metformin. }\end{array}$ & $\begin{array}{l}\text { Patients have to be stratified for risk of AKI } \\
\text { according to their susceptibilities, especially } \\
\text { preexisting proteinuria and CKD. }\end{array}$ & $\begin{array}{l}\text { Assess the risk for CI-AKI (in particular, screen } \\
\text { for pre-existing impairment of kidney function) in } \\
\text { all patients. }\end{array}$ \\
\hline \multicolumn{5}{|c|}{ Patient-related risk factor } \\
\hline Renal risk factors & $\begin{array}{l}\text { - eGFR }<45 \mathrm{ml} / \mathrm{min} / 1.73 \mathrm{~m} 2 \text { before i.a. ICM } \\
\text { administration with } 1^{\text {st }} \text { pass renal exposure or } \\
\text { in ICU patients. } \\
\text { - eGFR }<30 \mathrm{ml} / \mathrm{min} / 1.73 \mathrm{~m} 2 \text { before i.v. ICM } \\
\text { or i.a. ICM administration with } 2^{\text {nd }} \text { pass renal } \\
\text { exposure. } \\
\text { - Known or suspected acute renal failure }\end{array}$ & $\begin{array}{l}\text { eGFR }<30 \mathrm{~mL} / \mathrm{min} / 1.73 \mathrm{~m} 2 \text { seems to } \\
\text { be the threshold with the greatest level } \\
\text { of evidence. }\end{array}$ & $\begin{array}{l}\text { Precautions to reduce the risk should be } \\
\text { implemented in patients with a baseline } \\
\text { eGFR }<60 \mathrm{ml} / \mathrm{min} / 1.73 \mathrm{~m}^{2} \text {. This threshold } \\
\text { could probably be }<45 \mathrm{ml} / \mathrm{min} / 1.73 \mathrm{~m}^{2} \text { ). }\end{array}$ & $\begin{array}{l}\text { Precautions to reduce the risk should be } \\
\text { implemented in patients with a baseline eGFR }< \\
60 \mathrm{ml} / \mathrm{min} / 1.73 \mathrm{~m}^{2} \text {. This threshold could probably } \\
\left.\text { be }<45 \mathrm{ml} / \mathrm{min} / 1.73 \mathrm{~m}^{2}\right) \text {. }\end{array}$ \\
\hline Non-renal risk factors & $\begin{array}{l}\text { Non-renal risk factors are risk factors for the } \\
\text { presence of CKD or AKI, and are not specific } \\
\text { for post-contrast AKI }\end{array}$ & $\begin{array}{l}\text { Multiple other non-renal risk factors } \\
\text { have not been rigorously confirmed. }\end{array}$ & $\begin{array}{l}\text { - Diabetes } \\
\text { - Dehydration } \\
\text { - Nephrotoxic medications }\end{array}$ & $\begin{array}{l}\text { - Diabetes } \\
\text { - Hypertension } \\
\text { - Congestive heart failure } \\
\text { - Advanced age } \\
\text { - Volume depletion } \\
\text { - Hemodynamic instability } \\
\text { - Nephrotoxic medications }\end{array}$ \\
\hline \multicolumn{5}{|l|}{ Prevention strategies } \\
\hline Nephrotoxic medications & $\begin{array}{l}\text { There is insufficient evidence to recommend } \\
\text { withholding nephrotoxic drugs before CM } \\
\text { administration. } \\
\text { Stop metformine if eGFR }<30 \mathrm{ml} / \mathrm{min} / 1.73 \mathrm{~m}^{2} \\
\text { or all patients receiving i.a. ICM with } 1^{\text {st }} \text { renal } \\
\text { pass exposure or patient with AKI. }\end{array}$ & $\begin{array}{l}\text { Stop metfomine in patients with AKI or } \\
\text { severe CKD (eGFR < 30), or are } \\
\text { undergoing i.a. catheter studies that } \\
\text { might result in emboli to the renal } \\
\text { arteries. }\end{array}$ & $\begin{array}{l}\text { Nephrotoxic medications would have to be } \\
\text { stopped for days or even weeks, and not only } \\
\text { hours, before ICM administration. }\end{array}$ & $\begin{array}{l}\text { Nephrotoxic medication should preferably be } \\
\text { stopped. }\end{array}$ \\
\hline Preventive i.v. hydration & $\begin{array}{l}\text { For i.v. and i.a. ICM administration with } 2^{\text {nd }} \\
\text { pass renal exposure: } \\
\text { - i.v. sodium bicarbonate } 1.4 \%: 3 \mathrm{ml} / \mathrm{kg} / \mathrm{h} \text { for } \\
\text { 1h before ICM } \\
\text { - or i.v. saline } 0.9 \%: 1 \mathrm{ml} / \mathrm{kg} / \mathrm{h} \text { for } 3-4 \mathrm{~h} \text { before }\end{array}$ & $\begin{array}{l}\text { One possible protocol would be } 0.9 \% \\
\text { saline at } 100 \mathrm{~mL} / \mathrm{h} \text {, beginning } 6-12 \mathrm{~h} \\
\text { before and continuing } 4-12 \mathrm{~h} \text { after. }\end{array}$ & $\begin{array}{l}\text { i.v. volume expansion with either isotonic } \\
\text { sodium chloride or sodium bicarbonate } \\
\text { solutions, in patients at risk. }\end{array}$ & $\begin{array}{l}\text { i.v. volume expansion with either isotonic sodium } \\
\text { chloride or sodium bicarbonate solutions in } \\
\text { patients at risk. } \\
\geq 1.0-1.5 \mathrm{ml} / \mathrm{kg} / \mathrm{h} \text { of i.v. fluid has to be injected }\end{array}$ \\
\hline
\end{tabular}




\begin{tabular}{|c|c|c|c|c|}
\hline & $\begin{array}{l}\text { and 4-6h after ICM. } \\
\text { For i.a. ICM administration with } 1^{\text {st }} \text { renal } \\
\text { exposure: } \\
\text { - i.v. sodium bicarbonate } 1.4 \%: 3 \mathrm{ml} / \mathrm{kg} / \mathrm{h} \text { for } \\
1 \mathrm{~h} \text { before and } 1 \mathrm{ml} / \mathrm{kg} / \mathrm{h} \text { for } 4-6 \mathrm{~h} \text { after ICM } \\
\text { - or i.v. saline } 0.9 \%: 1 \mathrm{ml} / \mathrm{kg} / \mathrm{h} \text { for } 3-4 \mathrm{~h} \text { before } \\
\text { and } 4-6 \mathrm{~h} \text { after ICM. }\end{array}$ & & & $\begin{array}{l}\text { for } 3-12 \mathrm{~h} \text { before and } 6-12 \mathrm{~h} \text { after ICM exposure, } \\
\text { in order to achieve a urine flow rate of at least } 150 \\
\mathrm{ml} / \mathrm{h} \text {. }\end{array}$ \\
\hline $\begin{array}{l}\text { Other pharmacological } \\
\text { preventions strategies }\end{array}$ & $\begin{array}{l}\text { No other pharmacological prophylaxis }(\mathrm{N}- \\
\text { acetylcysteine, statins...) are recommended. }\end{array}$ & $\begin{array}{l}\text { There is insufficient evidence of } \mathrm{N}- \\
\text { acetylcysteine efficacy to recommend } \\
\text { its use. }\end{array}$ & $\begin{array}{l}\text { Use oral N-acetylcysteine only in patients } \\
\text { who receive appropriate fluid and salt } \\
\text { loading. }\end{array}$ & $\begin{array}{l}\text { Use oral } \mathrm{N} \text {-acetylcysteine together with i.v. } \\
\text { isotonic crystalloids, in patients at risk. }\end{array}$ \\
\hline \multirow{4}{*}{$\begin{array}{l}\text { Iodinated contrast- } \\
\text { media }\end{array}$} & \multicolumn{4}{|c|}{ Consider an alternative imaging method not using ICM. } \\
\hline & Osmolarity: use low or iso-osmolar ICM. & $\begin{array}{l}\text { Osmolarity: use low or iso-osmolar } \\
\text { ICM. }\end{array}$ & - & $\begin{array}{l}\text { Osmolarity: use either iso-osmolar or low- } \\
\text { osmolar ICM, in patients at risk. }\end{array}$ \\
\hline & $\begin{array}{l}\text { Dose: use the lowest dose of ICM consistent } \\
\text { with a diagnostic result. } \\
\text { - For i.v. ICM administration, there is } \\
\text { insufficient evidence that CM dose is a risk } \\
\text { factor. } \\
\text { - For i.a. ICM administration with } 1^{\text {st }} \text { pass } \\
\text { renal exposure keep either the ratio ICM dose } \\
\text { (in gram iodine / absolute eGFR (in } \mathrm{ml} / \mathrm{min} \text { ) } \\
<1.1 \text { or the ratio ICM volume (in } \mathrm{ml} / \mathrm{mGFR} \\
\text { (in } \mathrm{ml} / \mathrm{min} / 1.73 \mathrm{~m} 2 \text { ) }<3.0 \text { (ICM of } 350 \mathrm{mg} \\
\text { iodine/ml). }\end{array}$ & $\begin{array}{l}\text { Dose: use the lowest possible dose of } \\
\text { ICM (there is insufficient evidence to } \\
\text { recommend a specific threshold of ICM } \\
\text { volume). }\end{array}$ & - & $\begin{array}{l}\text { Dose: use the lowest possible dose of ICM, in } \\
\text { patients at risk. }\end{array}$ \\
\hline & $\begin{array}{l}\text { Repeated injections: repeated ICM injections } \\
\text { in a short period }(48-72 \mathrm{~h} \text { ) should be avoided }\end{array}$ & $\begin{array}{l}\text { Repeated injections: there is } \\
\text { insufficient evidence to specifically } \\
\text { endorse the decision to withhold a repeat } \\
\text { ICM injection until }>24 \mathrm{~h} \text { have passed } \\
\text { since the prior injection. }\end{array}$ & - & $\begin{array}{l}\text { Repeated injections: should be delayed for } 48 \mathrm{~h} \\
\text { in patients without risk factors and for } 72 \mathrm{~h} \text { in } \\
\text { those with diabetes mellitus or pre-existing CKD. } \\
\text { If acute renal dysfunction develops after ICM } \\
\text { administration, repeated exposure should } \\
\text { preferably be delayed until the serum creatinine } \\
\text { level has returned to baseline levels. }\end{array}$ \\
\hline
\end{tabular}


Table 5: Meta-analysis of randomized controlled studies on the use of statins in the prevention of iodinated contrast media-induced renal toxicity, following angiography.* Only randomized studies evaluated by this meta-analysis have been included in the table.

\begin{tabular}{|c|c|c|c|c|c|c|c|c|}
\hline Author, journal & $\begin{array}{c}\text { Publication } \\
\text { year }\end{array}$ & $\begin{array}{l}\text { Studies } \\
\text { (n) }\end{array}$ & $\begin{array}{l}\text { Patients } \\
\text { (n) }\end{array}$ & Intervention & $\begin{array}{c}\text { Pooled Risk Ratio } \\
\text { or Odds Ratio } \\
\text { [CI 95\%] ; p } \\
\end{array}$ & Statistical model & $\begin{array}{l}\text { Heterogeneity: } \\
\qquad \mathbf{I}^{2}\end{array}$ & $\begin{array}{c}\text { Publication bias: } \\
\text { funnel plot, } \\
\text { Egger's or Begg's tests }\end{array}$ \\
\hline $\begin{array}{l}\text { Zhang BC, et al, } \\
\text { Can J Cardiol. [83] }\end{array}$ & 2011 & 8 & 1423 & $\begin{array}{l}\text { High-dose statin versus } \\
\text { low-dose or placebo }\end{array}$ & $\begin{array}{c}0.51[0.34-0.77] \\
p=0.001\end{array}$ & Fixed-effects model & $\mathrm{I}^{2}=0 \%$ & $\begin{array}{c}\text { Yes (asymmetric) } \\
\text { Begg's test: } p=0.764\end{array}$ \\
\hline $\begin{array}{l}\text { Zhou Y, et al } \\
\text { Clin Nephrol. [84] }\end{array}$ & 2011 & 5 & 1009 & $\begin{array}{l}\text { High-dose statin versus } \\
\text { low-dose or placebo }\end{array}$ & $\begin{array}{c}0.53[0.32-0.87] \\
p=0.01\end{array}$ & $\begin{array}{l}\text { Mantel-Haenszel fixed- } \\
\text { effects model }\end{array}$ & $\mathrm{I}^{2}=19 \%$ & $\begin{array}{c}\text { Yes (asymmetric) } \\
\text { Egger's test: } p=0.27\end{array}$ \\
\hline $\begin{array}{l}\text { Takagi H, et al } \\
\text { Int J Cardiol. [92] }\end{array}$ & 2011 & 7 & 1251 & $\begin{array}{c}\text { Statin (atorvastatin) versus } \\
\text { low-dose or placebo or } \\
\text { other statin }\end{array}$ & $\begin{array}{c}0.56[0.33-0.95] \\
p=0.03\end{array}$ & Fixed-effects model & $\mathrm{I}^{2}=0 \%$ & $\begin{array}{l}\text { Yes (but not shown) } \\
\text { Egger's test: } p=0.29\end{array}$ \\
\hline $\begin{array}{l}\text { Zhang L, et al } \\
\text { Int J Clin Pract. [104] }\end{array}$ & 2011 & 4 & 751 & Statin versus no statin & $\begin{array}{c}0.76[0.44-1.29] \\
p=0.30\end{array}$ & Random-effects model & $\mathrm{I}^{2}=0 \%$ & 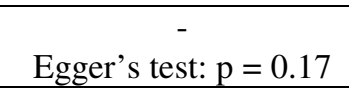 \\
\hline $\begin{array}{l}\text { Pappy R, et al } \\
\text { Int J Cardiol*. [105] }\end{array}$ & 2011 & 3 & 770 & $\begin{array}{l}\text { Statin versus hydration } \\
\text { and/or placebo }\end{array}$ & $\begin{array}{c}0.76[0.41-1.41] \\
p=0.39\end{array}$ & $\begin{array}{l}\text { Der Simonian and Laird } \\
\text { random-effects model }\end{array}$ & $\mathrm{I}^{2}=0 \%$ & $\begin{array}{l}- \\
-\end{array}$ \\
\hline $\begin{array}{l}\text { Zhang T, et al } \\
\text { Am J nephrol. [106] }\end{array}$ & 2011 & 6 & 1194 & $\begin{array}{l}\text { High-dose statin versus } \\
\text { low-dose or placebo }\end{array}$ & $\begin{array}{c}0.70[0.48-1.02] \\
\mathrm{p}=0.06\end{array}$ & Fixed-effects model & $\mathrm{I}^{2}=38 \%$ & $\begin{array}{l}- \\
-\end{array}$ \\
\hline $\begin{array}{l}\text { Li Y, et al } \\
\text { PLoS One. [85] }\end{array}$ & 2012 & 7 & 1399 & $\begin{array}{l}\text { High-dose statin versus } \\
\text { low-dose or placebo }\end{array}$ & $\begin{array}{c}0.51[0.34-0.76] \\
\mathrm{p}=0.001\end{array}$ & Fixed-effects model & $\mathrm{I}^{2}=0 \%$ & $\begin{array}{c}\text { Yes (asymmetric) } \\
-\end{array}$ \\
\hline $\begin{array}{l}\text { Giacoppo D, et al } \\
\text { Am J Cardiol. [86] }\end{array}$ & 2014 & 8 & 4984 & Statin versus no statin & $\begin{array}{c}0.54[0.38-0.78] \\
p=0.001\end{array}$ & $\begin{array}{l}\text { Der Simonian and Laird } \\
\text { random-effect model }\end{array}$ & $\mathrm{I}^{2}=42 \%$ & $\begin{array}{c}\text { Yes (asymmetric) } \\
\text { Egger's test: } p=0.218\end{array}$ \\
\hline $\begin{array}{l}\text { Lee JM, et al } \\
\text { Plos One. [87] }\end{array}$ & 2014 & 13 & 5825 & $\begin{array}{l}\text { High-dose statin versus } \\
\text { low-dose or placebo }\end{array}$ & $\begin{array}{c}0.45[0.35-0.57] \\
\mathrm{p}<0.001\end{array}$ & $\begin{array}{l}\text { Der Simonian and Laird } \\
\text { random-effects model }\end{array}$ & $\mathrm{I}^{2}=8.2 \%$ & $\begin{array}{c}\text { Yes } \\
\text { Egger's test: } p=0.13 \\
\text { Begg's test: } p=0.62\end{array}$ \\
\hline $\begin{array}{l}\text { Ukaigwe A, et al } \\
\text { Am J Cardiol. [88] }\end{array}$ & 2014 & 12 & 5564 & $\begin{array}{l}\text { High-dose statin versus } \\
\text { low-dose or placebo }\end{array}$ & $\begin{array}{c}0.43[0.33-0.55] \\
\mathrm{p}<0.001 \\
\end{array}$ & Random-effects model & $\mathrm{I}^{2}=19 \%$ & $\begin{array}{c}\text { Yes } \\
- \\
\end{array}$ \\
\hline $\begin{array}{l}\text { Marenzi G, et al } \\
\text { Int J Cardiol. [89] }\end{array}$ & 2015 & 9 & 5212 & $\begin{array}{l}\text { High-dose statin versus } \\
\text { low-dose or placebo }\end{array}$ & $\begin{array}{c}0.50[0.39-0.64] \\
\mathrm{p}<0.001\end{array}$ & $\begin{array}{l}\text { Mantel-Haenszel fixed- } \\
\text { effects model }\end{array}$ & $\mathrm{I}^{2}=1 \%$ & $\begin{array}{c}\text { Yes } \\
\text { Egger's test: } p=0.51\end{array}$ \\
\hline $\begin{array}{l}\text { Wu H, et al } \\
\text { J Clin Pharmacol. [90] }\end{array}$ & 2015 & 14 & 1689 & $\begin{array}{l}\text { High-dose statin } \\
\text { versus low-dose }\end{array}$ & $\begin{array}{c}0.41[0.29-0.56] \\
\mathrm{p}<0.05\end{array}$ & Fixed-effects model & $\mathrm{I}^{2}=0 \%$ & $\begin{array}{c}- \\
\text { Egger's test: } p=0.27 \\
\text { Begg's test: } p=0.88\end{array}$ \\
\hline $\begin{array}{l}\text { Liu YH, et al } \\
\text { J Cardiovasc Pharmacol } \\
\text { Ther. [91] }\end{array}$ & 2015 & 9 & 5143 & Statin versus placebo & $\begin{array}{c}0.47[0.37-0.60] \\
\mathrm{p}<0.0001\end{array}$ & Fixed-effects model & $\mathrm{I}^{2}=28 \%$ & $\begin{array}{c}\text { Yes } \\
\text { Egger's test: } p=0.352\end{array}$ \\
\hline
\end{tabular}




\begin{tabular}{|c|c|c|c|c|c|c|c|c|}
\hline $\begin{array}{l}\text { Yang Y, et al } \\
\text { Medicine (Baltimore). [93] }\end{array}$ & 2015 & 5 & 4045 & $\begin{array}{l}\text { Statin (rosuvastatin) } \\
\text { versus placebo }\end{array}$ & $\begin{array}{c}0.49[0.37-0.66] \\
p<0.001\end{array}$ & Fixed-effects model & $\mathrm{I}^{2}=30 \%$ & $\begin{array}{c}\text { Yes } \\
\text { Egger's test: } p=0.231\end{array}$ \\
\hline $\begin{array}{l}\text { Cheungpasitporn W, et al } \\
\text { Ren fail. [94] }\end{array}$ & 2015 & 13 & 5803 & $\begin{array}{c}\text { Statin versus } \\
\text { low-dose or placebo }\end{array}$ & $\begin{array}{c}0.49[0.37-0.66] \\
p<0.00001\end{array}$ & Random-effect model & $\mathrm{I}^{2}=25 \%$ & $\begin{array}{c}\text { Yes (asymmetric) } \\
-\end{array}$ \\
\hline $\begin{array}{l}\text { Wang } N \text {, et al } \\
\text { Int } J \text { cardiol. [95] }\end{array}$ & 2016 & 14 & 6033 & $\begin{array}{l}\text { High-dose statin versus } \\
\text { low-dose or placebo }\end{array}$ & $\begin{array}{c}0.46[0.36-0.58] \\
\mathrm{p}<0.00001\end{array}$ & Random-effects model & $\mathrm{I}^{2}=8 \%$ & $\begin{array}{l}\text { Yes (asymmetric) } \\
\text { Egger's test: } \mathrm{p}=0.20 \\
\text { Begg's test: } \mathrm{p}=0.91\end{array}$ \\
\hline $\begin{array}{l}\text { Zografos TA, et al } \\
\text { J Am Coll Cardiol. [96] }\end{array}$ & 2016 & 7 & 5174 & $\begin{array}{l}\text { High-dose statin versus } \\
\text { low-dose or placebo }\end{array}$ & $\begin{array}{c}0.50[0.38-0.66] \\
\mathrm{p}<0.001\end{array}$ & Random-effects model & $\mathrm{I}^{2}=19 \%$ & $\begin{array}{l}- \\
-\end{array}$ \\
\hline $\begin{array}{l}\text { Liang M, et al } \\
\text { Medicine (Baltimore). [97] }\end{array}$ & 2017 & 15 & 2673 & $\begin{array}{l}\text { Moderate or high-dose statin } \\
\text { (rosuvastatine) } \\
\text { versus low-dose or placebo }\end{array}$ & $\begin{array}{c}0.45[0.35-0.58] \\
\mathrm{p}<0.0001\end{array}$ & Fixed-effects model & $\mathrm{I}^{2}=0 \%$ & $\begin{array}{c}\text { Yes } \\
-\end{array}$ \\
\hline
\end{tabular}




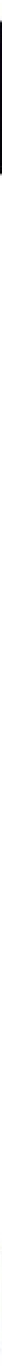




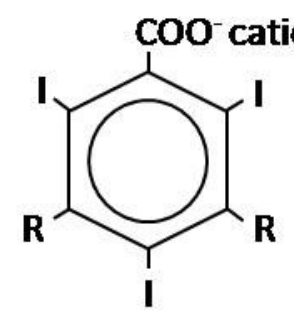

Ionic monomer

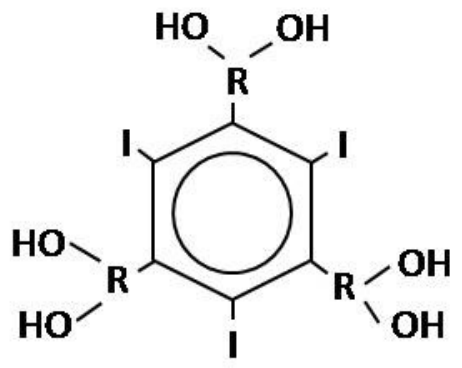

Non ionic monomer

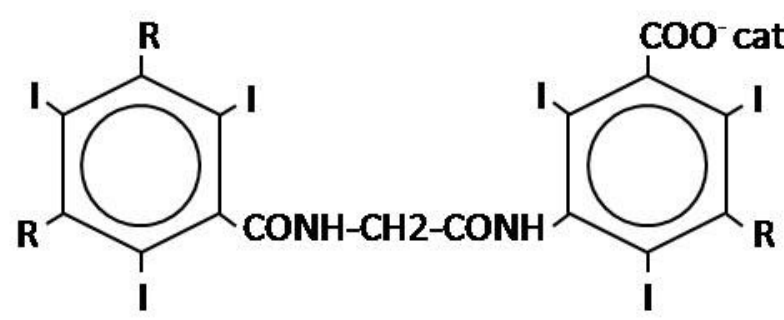

Ionic dimer

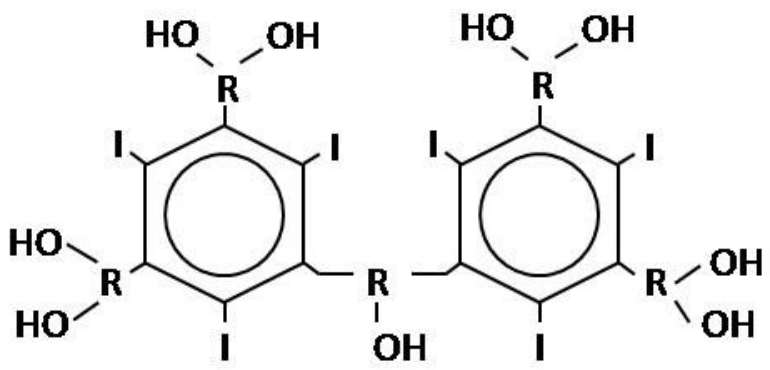

Non ionic dimer 